\title{
Party System Volatility in Post-Communist Europe ${ }^{\Uparrow}$
}

\author{
Charles CRABTREe' \\ Pennsylvania State University \\ MATt GoldeR \\ Pennsylvania State University
}

\begin{abstract}
In their 2014 article in the British Journal of Political Science, Eleanor Neff Powell and Joshua A. Tucker examine the determinants of party system volatility in post-communist Europe. Their central conclusion is that replacement volatility - volatility caused by new party entry and old party exit - is driven by longterm economic performance. We show that this conclusion is based entirely on a miscalculation of the long-term economic performance of a single country, Bosnia-Herzegovina. Our reanalysis suggests that we know little about what causes party system volatility in post-communist Europe. Given the negative consequences traditionally associated with party system volatility, this area of research cries out for new theoretical development.
\end{abstract}

*NOTE: We thank Sarah Birch, Chris Fariss, and Sona Nadenichek Golder for their helpful comments on this paper. We also thank Eleanor Powell, Joshua Tucker, and Grigore Pop-Eleches for providing data and comments during the replication process. All data and computer code necessary to verfiy the results in this analysis will be made publicly available at https://github.com/cdcrabtree and http://homepages.nyu.edu/mrg217/public/ on publication. Stata 12 and R 3.1.0 were the statistical packages used in this study.

${ }^{\dagger}$ Corresponding Author: Graduate Student, Pennsylvania State University, Department of Political Science, 203 Pond Lab, University Park, PA 16802 (charles.crabtree@psu.edu).

${ }^{\ddagger}$ Associate Professor, Pennsylvania State University, Department of Political Science, 306 Pond Lab, University Park, PA 16802 (mgolderepsu .edu). Tel: 814-867-4323. Fax: 814-863-8979. 
In their well-cited 2014 article in the British Journal of Political Science, Eleanor Neff Powell and Joshua A. Tucker examine party system volatility in post-communist Europe 1 Following Birch (2001, 2003), they highlight the importance of disaggregating volatility into two components: volatility caused by new party entry and old party exit, and volatility caused by vote switching across existing parties. Whereas Birch refers to these components as "replacement volatility" and "electoral volatility", Powell and Tucker refer to them as "Type A Volatility" and "Type B Volatility." Standard measures of volatility, such as the well-known Pedersen Index (1983), conflate these different components of volatility. This is problematic if the two components of volatility have different causes and consequences.

The extent to which party system volatility is driven by replacement and electoral volatility is likely to vary across different contexts. In particular, one would expect replacement volatility to play a larger role in democratizing countries where parties form, disappear, split, and merge as they adapt to a new electoral and institutional environment than in established democracies where the identities of the parties have stabilized (Birch 2003, 121). Powell and Tucker $(2014,9)$ provide support for this claim when they show that volatility is primarily driven by replacement volatility in the post-communist countries of Eastern Europe but by electoral volatility in the established democracies of Western Europe. In this note, we challenge their central claim that replacement volatility in post-communist Europe is driven by long-term economic performance.

Powell and Tucker provide measures of replacement and electoral volatility, and show how they relate to the standard indicator of party system volatility, the Pedersen Index ${ }^{2}$

$$
\begin{aligned}
\text { Replacement Volatility (Type A) } & =\frac{\left|\sum_{o=1}^{n} p_{o t}+\sum_{w=1}^{n} p_{w(t+1)}\right|}{2}, \\
\text { Electoral Volatility (Type B) } & =\frac{\sum_{i=1}^{n}\left|p_{i t}-p_{i(t+1)}\right|}{2} \text { among all stable parties, }
\end{aligned}
$$

Total Volatility $($ Pedersen Index $)=\frac{\sum_{i=1}^{n}\left|p_{i t}-p_{i(t+1)}\right|}{2}=$ Replacement Volatility + Electoral Volatility,

where $p$ refers to a party's vote share, $o$ refers to parties that contested only the election at time $t, w$ refers to parties that contested only the election at time $t+1$, and stable parties refer to those parties that competed in elections at times $t$ and $t+1$. They then calculate volatility across 89 pairs of elections in 21 post-communist

\footnotetext{
${ }^{1}$ According to Google Scholar, Powell and Tucker's article, along with its working paper versions, have already been cited 81 times by the end of November 2014 (http: / / bit. 1y/1p 7cKVy).

${ }^{2}$ Birch (2003, 123-124) provides two measures of electoral volatility, one of which is the same as Powell and Tucker's Type B Volatility; her measure of replacement volatility differs from Powell and Tucker's Type A Volatility.
} 
countries from 1989 to 2009. Their data comprise the largest dataset on volatility in post-communist Europe and represent a valuable contribution to the existing literature.

Table 1: Electoral and Replacement Volatility in Post-Communist Europe

\begin{tabular}{|c|c|c|c|c|c|c|}
\hline & \multicolumn{2}{|c|}{ Verification } & \multicolumn{2}{|c|}{ Without Bosnia-Herzegovina } & \multicolumn{2}{|c|}{ Corrected Bosnia-Herzegovina } \\
\hline & $\begin{array}{l}\text { Electoral } \\
\text { Volatility }\end{array}$ & $\begin{array}{c}\text { Replacement } \\
\text { Volatility }\end{array}$ & $\begin{array}{l}\text { Electoral } \\
\text { Volatility }\end{array}$ & $\begin{array}{l}\text { Replacement } \\
\text { Volatility }\end{array}$ & $\begin{array}{l}\text { Electoral } \\
\text { Volatility }\end{array}$ & $\begin{array}{l}\text { Replacement } \\
\text { Volatility }\end{array}$ \\
\hline GDP Change from 1989 & $\begin{array}{c}0.639 \\
(0.693)\end{array}$ & $\begin{array}{c}-4.623^{* * *} \\
(1.326)\end{array}$ & $\begin{array}{c}0.116 \\
(3.206)\end{array}$ & $\begin{array}{l}-6.066 \\
(7.178)\end{array}$ & $\begin{array}{c}0.004 \\
(3.233)\end{array}$ & $\begin{array}{l}-6.002 \\
(6.609)\end{array}$ \\
\hline GDP Change Between Elections & $\begin{array}{l}-2.059 \\
(5.219)\end{array}$ & $\begin{array}{c}9.019 \\
(10.128)\end{array}$ & $\begin{array}{l}-1.891 \\
(5.898)\end{array}$ & $\begin{array}{c}6.677 \\
(10.704)\end{array}$ & $\begin{array}{l}-1.076 \\
(5.229)\end{array}$ & $\begin{array}{c}4.576 \\
(10.064)\end{array}$ \\
\hline Effective Number of Electoral Parties & $\begin{array}{c}0.446 \\
(0.313)\end{array}$ & $\begin{array}{l}-0.346 \\
(0.533)\end{array}$ & $\begin{array}{c}0.452 \\
(0.316)\end{array}$ & $\begin{array}{l}-0.264 \\
(0.558)\end{array}$ & $\begin{array}{c}0.471 \\
(0.326)\end{array}$ & $\begin{array}{l}-0.462 \\
(0.546)\end{array}$ \\
\hline Log Weighted District Magnitude & $\begin{array}{l}-0.784 \\
(0.887)\end{array}$ & $\begin{array}{c}0.638 \\
(2.931)\end{array}$ & $\begin{array}{l}-0.789 \\
(0.882)\end{array}$ & $\begin{array}{c}0.603 \\
(2.893)\end{array}$ & $\begin{array}{l}-0.824 \\
(0.886)\end{array}$ & $\begin{array}{c}0.820 \\
(2.872)\end{array}$ \\
\hline Presidential System & $\begin{array}{l}-4.631 \\
(4.126)\end{array}$ & $\begin{array}{c}6.784 \\
(9.435)\end{array}$ & $\begin{array}{l}-4.847 \\
(4.606)\end{array}$ & $\begin{array}{c}5.532 \\
(10.241)\end{array}$ & $\begin{array}{l}-4.928 \\
(4.623)\end{array}$ & $\begin{array}{c}6.659 \\
(10.296)\end{array}$ \\
\hline Semi-Presidential System & $\begin{array}{l}-2.788 \\
(2.211)\end{array}$ & $\begin{array}{c}4.255 \\
(5.897)\end{array}$ & $\begin{array}{l}-2.813 \\
(2.286)\end{array}$ & $\begin{array}{c}4.017 \\
(5.885)\end{array}$ & $\begin{array}{l}-2.596 \\
(2.266)\end{array}$ & $\begin{array}{c}2.621 \\
(5.887)\end{array}$ \\
\hline Proportional Representation & $\begin{array}{c}0.827 \\
(2.228)\end{array}$ & $\begin{array}{c}0.077 \\
(6.004)\end{array}$ & $\begin{array}{c}0.852 \\
(2.265)\end{array}$ & $\begin{array}{l}-0.146 \\
(5.943)\end{array}$ & $\begin{array}{c}0.987 \\
(2.223)\end{array}$ & $\begin{array}{l}-0.739 \\
(5.948)\end{array}$ \\
\hline Ethnic Fractionalization & $\begin{array}{l}-6.163 \\
(6.397)\end{array}$ & $\begin{array}{c}-2.677 \\
(18.978)\end{array}$ & $\begin{array}{l}-6.716 \\
(6.784)\end{array}$ & $\begin{array}{c}-5.298 \\
(22.939)\end{array}$ & $\begin{array}{l}-5.713 \\
(6.772)\end{array}$ & $\begin{array}{l}-11.828 \\
(22.931)\end{array}$ \\
\hline Years Since Collapse of Communism & $\begin{array}{c}0.848 \\
(0.807)\end{array}$ & $\begin{array}{l}-2.633 \\
(2.153)\end{array}$ & $\begin{array}{c}0.828 \\
(0.863)\end{array}$ & $\begin{array}{l}-1.989 \\
(2.117)\end{array}$ & $\begin{array}{c}0.732 \\
(0.797)\end{array}$ & $\begin{array}{l}-1.959 \\
(1.976)\end{array}$ \\
\hline Years Since Collapse Squared & $\begin{array}{l}-0.031 \\
(0.042)\end{array}$ & $\begin{array}{c}0.070 \\
(0.101)\end{array}$ & $\begin{array}{l}-0.029 \\
(0.044)\end{array}$ & $\begin{array}{c}0.045 \\
(0.097)\end{array}$ & $\begin{array}{l}-0.026 \\
(0.043)\end{array}$ & $\begin{array}{c}0.049 \\
(0.093)\end{array}$ \\
\hline Constant & $\begin{array}{c}13.059^{* *} \\
(5.318)\end{array}$ & $\begin{array}{c}41.941^{* * *} \\
(13.329)\end{array}$ & $\begin{array}{c}13.586^{* * *} \\
(5.115)\end{array}$ & $\begin{array}{c}43.661^{* * *} \\
(14.057)\end{array}$ & $\begin{array}{c}12.885^{* *} \\
(5.034)\end{array}$ & $\begin{array}{c}48.191^{* * *} \\
(14.509)\end{array}$ \\
\hline Countries & 21 & 21 & 20 & 20 & 21 & 21 \\
\hline Pairs of Elections & 89 & 89 & 86 & 86 & 89 & 89 \\
\hline $\mathrm{R}^{2}$ & 0.116 & 0.139 & 0.114 & 0.119 & 0.112 & 0.109 \\
\hline
\end{tabular}

Note: Robust standard errors clustered by country are in parentheses. Replacement Volatility (Type A Volatility) refers to volatility caused by new party entry and old party exit. Electoral Volatility (Type B Volatility) refers to volatility caused by vote switching across existing parties. The first two columns correspond exactly to the results found in Powell and Tucker's preferred model (Model 4) in their Tables 3 and 5 (2014, 16-17). Following Powell and Tucker (2014, fn. 34), we do not report the coefficients on a dummy variable that identifies four observations for which information on district magnitude is missing. The next two columns correspond to a model where we omit the three "unusual" observations from Bosnia-Herzegovina. The last two columns correspond to a model where we substitute in the "correct" GDP Change from 1989 values for the three Bosnia-Herzegovina observations.

Powell and Tucker use their data to reexamine the causes of party system volatility in post-communist countries. Specifically, they investigate how a host of economic, political, and institutional variables that have been employed in previous studies affect replacement and electoral volatility $\left.\right|^{3}$ Their results, which we were able to verify (Herrnson 1995), are shown in the first two columns of Table 1 . As the results in the first

\footnotetext{
${ }^{3}$ For specific information on each of the covariates, see Powell and Tucker (2014, 13-15).
} 
column indicate, there is no evidence that electoral volatility varies in a statistically significant way with any of the covariates from the existing theoretical literature.

As already indicated, though, the vast majority of party system volatility in post-communist Europe is driven by replacement volatility. The results in the second column of Table 1 indicate that GDP Change from 1989 is the only statistically significant determinant of replacement volatility. GDP Change from 1989 is calculated as the ratio of GDP in a given election year to GDP in 1989, and is designed to "tap into overall voter satisfaction with the performance of the current government ... relative to the previous communist era" $(2014,13)$. The negative and statistically significant coefficient on GDP Change from 1989 indicates that replacement volatility decreases with "long-term economic recovery" $(2014,1)$. Powell and Tucker $(2014$, 21) state that "such a finding fits in very well with big-picture theoretical ideas about the extended role of the transition in structuring post-communist political behavior (Kitschelt et al. 1999, Tucker 2006)."

As we now demonstrate, though, there are strong reasons to doubt the claim that long-term economic performance is driving replacement volatility in post-communist Europe. In Figure 1, we plot replacement

Figure 1: Replacement Volatility and Long-Term Economic Performance in Post-Communist Europe

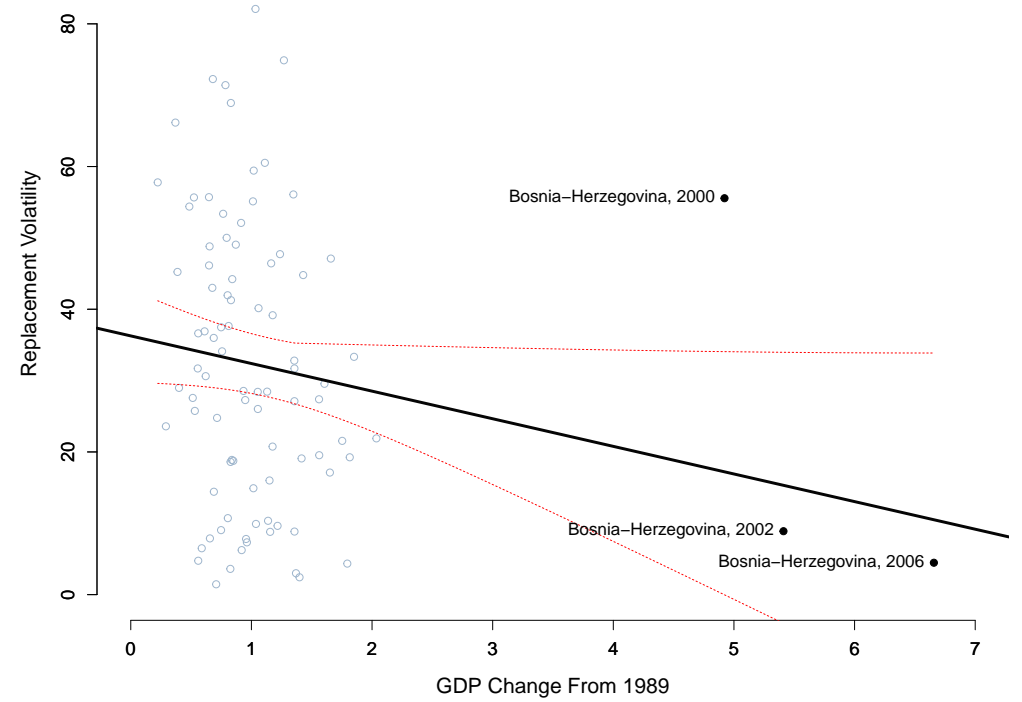

Note: The figure shows replacement volatility (Type A volatility) plotted against GDP Change from 1989 for 89 pairs of elections in 21 postcommunist countries from 1989 to 2009 . The downward-sloping solid black line represents the fitted values from a bivariate regression; the red dashed lines represent two-tailed 95\% confidence intervals. GDP Change from 1989 is calculated as the ratio of GDP in a given election year to GDP in 1989. Values less than 1 indicate that election-year GDP is less than GDP in 1989, whereas values greater than 1 indicate how many times larger election-year GDP is compared to GDP in 1989. 
volatility against GDP Change from 1989. Recall that values of GDP Change from 1989 less than one indicate that election-year GDP is less than GDP in 1989, and that values greater than one indicate how many times larger election-year GDP is compared to GDP in 1989. The downward-sloping solid black line represents the fitted values from a bivariate regression of replacement volatility against GDP Change from 1989; the dashed red lines represent two-tailed $95 \%$ confidence intervals.

It should be immediately clear that the three observations from Bosnia-Herzegovina are distinct outliers with respect to GDP Change from 1989. Whereas the mean value of this covariate is 5.66 for BosniaHerzegovina, it is only $0.98(\sigma=0.39)$ for the remaining 86 observations. In fact, the average value for Bosnia-Herzegovina is fully 2.77 times larger than the next largest value, Poland 2007. An obvious concern is that the negative relationship between replacement volatility and long-term economic performance reported by Powell and Tucker is being driven by the unusual observations for Bosnia-Herzegovina.

To examine this possibility, we re-estimated our models after dropping the observations from BosniaHerzegovina. The results, which are shown in columns 3 and 4 of Table 1 indicate that none of the covariates discussed in the existing theoretical literature have a statistically significant effect on electoral or replacement volatility. Of most relevance here is the fact that there is no longer any evidence to support Powell and Tucker's claim that replacement volatility is driven by long-term economic performance. While the coefficient on GDP Change from 1989 remains negative, it is far from being statistically significant; indeed, the standard error is now larger than the coefficient. A jackknife procedure, where we sequentially drop each country one at at time and then re-estimate the models for each of the reduced datasets, reveals that it is only the outlier observations from Bosnia-Herzegovina that are substantively influencing the results.

It turns out, though, that the values of GDP Change from 1989 for Bosnia-Herzegovina are not just highly unusual, they are, in fact, incorrect. Recall that GDP Change from 1989 is supposed to be calculated as the ratio of GDP in a given election year to GDP in 1989. This variable comes from Pop-Eleches (2010), who obtained the underlying data from the European Bank for Reconstruction and Development (EBRD). This underlying data, which was kindly provided by Grigore Pop-Eleches, includes all the information necessary to calculate GDP Change from 1989 for every country in the sample except Bosnia-Herzegovina. The problem with Bosnia-Herzegovina is that the reported GDP data only goes back to 19944 Correspondence

\footnotetext{
${ }^{4}$ This explains why previous articles that have employed the GDP Change from 1989 variable have excluded BosniaHerzegovina from their analyses (Pop-Eleches 2010, Pacek, Pop-Eleches \& Tucker 2009).
} 
with Powell and Tucker reveal that they used 1994, instead of 1989, as the baseline year when calculating the values of GDP Change from 1989 for Bosnia-Herzegovina.

Although a choice like this might ordinarily be expected to cause few problems, this is not the case here. We were able to locate economic data back to 1989 for Bosnia-Herzegovina from the EBRD's more recent Transition Report 2012 (Zettelmeyer, Ricka \& Sanfey 2012, 103). In Figure2, we show how real GDP in Bosnia-Herzegovina varies over time using 1989 as the baseline year. It should be immediately obvious that Powell and Tucker's decision to use 1994 (the red circle) as the baseline year produces very misleading values for GDP Change since 1989. Unlike most of the countries in our sample, Bosnia-Herzegovina had to fight for its independence. The 1992-1995 Bosnian war essentially destroyed the nation's economy, something that is clearly visible in Figure 2. Bosnia-Herzegovina's GDP in 1994 was just $12.7 \%$ of what it was in 1989. Although GDP was more than five to six times larger in the 2000s than it was in 1994 (the values calculated by Powell and Tucker), it actually remained less than it was in 1989. Once we use 1989 as the baseline year, it soon becomes clear that the long-term economic performance of Bosnia-Herzegovina is not unusual at all - the mean value of GDP Change since 1989 is 0.64 , less than one standard deviation

Figure 2: Long-Term Economic Performance in Bosnia-Herzegovina, 1989-2012

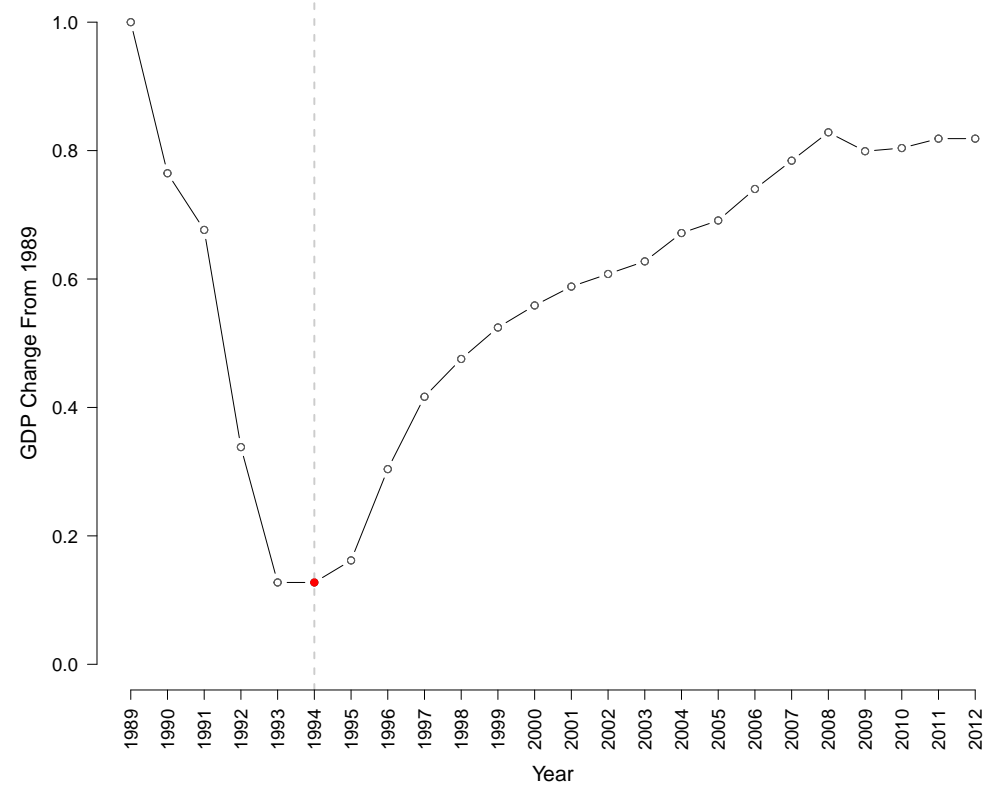

Note: Data on real GDP in Bosnia-Herzegovina come from the European Bank for Reconstruction and Development's Transition Report 2012 (Zettelmeyer, Ricka \& Sanfey 2012, 103). GDP is set to 1 in 1989. The red dot and vertical dashed gray line indicates the baseline year - $1994-$ used by Powell and Tucker (2014) for calculating GDP Change since 1989. 
away from the sample mean. In columns 5 and 6 of Table 1, we present results from models in which we substitute in the correct data for Bosnia-Herzegovina. There is no evidence that replacement (or electoral) volatility in post-communist Europe is driven by long-term economic performance.

In their recent article, Powell and Tucker revisit the determinants of party system volatility in postcommunist Europe. They conclude $(2014,1)$ that replacement volatility is "largely a function of long-term economic recovery." As we have demonstrated, though, this conclusion is based entirely on a miscalculation of the long-term economic performance of a single country, Bosnia-Herzegovina. To the extent that Powell and Tucker have correctly identified the key theoretical variables in the existing literature, our reanalysis suggests that we know little about what causes party system volatility in post-communist Europe. None of the variables they propose have a statistically significant effect on either electoral or replacement volatility. Given the negative consequences traditionally associated with party system volatility, this area of research cries out for new theoretical development. 


\section{References}

Birch, Sarah. 2001. "Electoral System and Party System Stability in Post-Communist Europe." Paper presented at the 2001 Annual Conference of the American Political Science Association, San Francisco, CA, 26-29 August.

Birch, Sarah. 2003. Electoral Systems and Political Transformation in Post-Communist Europe. Great Britain: Palgrave MacMillan.

Herrnson, Paul S. 1995. "Replication, Verification, Secondary Analysis, and Data Collection in Political Science." PS: Political Science and Politics 28:452-455.

Kitschelt, Herbert, Zdenka Manfeldova, Radoslaw Markowski \& Gabor Toka. 1999. Post-Communist Party Systems: Competition, Representation, and Inter-Party Cooperation. Cambridge: Cambridge University Press.

Pacek, Alexander C., Grigore Pop-Eleches \& Joshua A. Tucker. 2009. "Disenchanted or Discerning: Voter Turnout in Post-Communist Countries." Journa of Politics 71:473-491.

Pedersen, Mogens. 1983. "Changing Patterns of Electoral Volatility in European Party Systems". In Western European Party Systems: Continuity and Change, ed. Hans Daalder \& Peter Mair. Beverley Hills, CA: Sage pp. 29-66.

Pop-Eleches, Grigore. 2010. "Throwing Out the Bums: Protest Voting and Unorthodox Parties after Communism.” World Politics 62:221-260.

Powell, Eleanor Neff \& Joshua A. Tucker. 2014. "Revisiting Electoral Volatility in Post-Communist Countries: New Data, New Results, and New Approaches.” British Journal of Political Science 44:123-147.

Tucker, Joshua A. 2006. Regional Economic Voting: Russia, Poland, Hungary, Slovakia, and the Czech Republic, 1990-1999. New York: Cambridge University Press.

Zettelmeyer, Jeromin, Franto Ricka \& Peter Sanfey, eds. 2012. Transition Report 2012: Integration Across Borders. London: European Bank for Reconstruction and Development. 